TATIANA BEZPROZVANNA,

\title{
MONETARY IDENTIFICATION OF A PERSON AS A PRODUCT OF DISSEMINATION OF VALUES OF WESTERN CIVILIZATION
}

\begin{abstract}
The article is devoted to the problem of monetary identity, which needs a detailed study in the context of the transformation processes of the modern world. The relevance of the study is that the identity of modern man is becoming unsteady. In seeking guidance for constructing one's own "Self", a person finds himself at a crossroads. They lose the identity they had from birth as members of traditional society and are forced to build it independently. The article reveals the preconditions for the emergence of an identity crisis in the context of the development of capitalism and the formation of the economic man. The purpose of the article is to determine the peculiarities of the formation of monetary identity, which has become essentially a by-product of the spread of Western values. To achieve this goal, a structural-functional analysis of social interactions of the subjects of identification has been conducted, as well as general scientific methods of synthesis and generalization of materials, analysis, comparison, deductive and inductive methods, etc. have been used. The main features of monetary identity are that a person begins to be guided by one's own selfish principles, and money becomes the main value for such a person, appearing as a universal value that is equivalent to all other material values. In the modern world, monetary identity appears as a global and unstable one, it is formed artificially and serves the modern market for profit within the consumer society. It is concluded that in the modern world, money not only serves to improve the objective circumstances of life, but also becomes a means of achieving public recognition. The problem of monetary identity is especially relevant for Ukraine as a country that focuses on the Western type of management with its achievements, values and at the same time problems, and therefore requires further research.
\end{abstract}

Key words: monetary identification, identity, identity crisis, capitalism, money, monetary values, Western civilization.

\section{Introduction}

In the conditions of the modern pluralistic world, the problem of identification of the person is becoming extremely urgent. Identification begins to be considered as a complex process that is formed in the context of human socialization under certain historical and cultural conditions. The idea of human identity arises during the transition to the post-industrial stage of development of society in the form of a "crisis" in a person's awareness of one's own "self".

Researchers mostly distinguish different areas in the study of the problem of identity, including social, cultural, ethnic, group identity etc. However, in the framework of the functioning of social identity, monetary identity should be allocated, which is becoming increasingly important for determining the place of a man in the world.

There is an inverse relationship between a person's identity and the surrounding social space. Within a society, a certain identity is formed, and a person as a bearer of this identity receives a corresponding set of values, patterns of behavior, etc. Such social identity is not permanent and changes in accordance with changes in society. However, the very changes in society happen under the influence of human activity guided by identity.

Highlighting the main features of the modern world in which human self-determination takes place, Z. Bauman notes that in our time there is a lack of such patterns, codes and rules that can be obeyed and can be chosen as stable guidelines which man will be guided by. Of course, this does not mean that our contemporaries are guided solely by their own imagination and determination and are free to choose a way of life without relying on anything, or that society has stopped providing "building materials" and "schemes". The researcher believes that we are moving from the era of predetermined "reference groups" to the era of "universal comparison", in which it becomes difficult to determine the direction of efforts that must be made to successfully build one's life (Bauman, 2013: 7). Therefore, for the inhabitants of "liquid modernity", identity is constantly flowing, it covers various spheres of life and is determined in all human activities.

According to Sitkevich N.V., the problem of identity becomes important because a person in the modern world does not stop trying to grasp for identity, seeks it as a certain support in life, a certain model of behavior, or collects it from scattered pieces of identification. For a person living in a world of intense ideological and social motivations, the process of identification solves many problems of the individual, and through them society itself: a person finds an existence identical to their essence; gets the opportunity to solve the problem of loneliness and historical continuity (Sitkevich, 2011: 149).

In the fluid world, a person feels the need for certain marks, which can be found only by defining one's own 
identity. If earlier the search for identity did not cause special difficulties, now a person, observing the course of events, simply does not have time to form clear boundaries of the personality. In the search for at least a partial solution to the problem of identity, people turn to money as a universal tool. Money allows a person to feel stable, and consumption subjectively seems to be at least a sign that a person exists at all.

A characteristic feature of the modern world is that money penetrates into all spheres of human existence, the so-called "monetary culture" or "financial civilization" is formed, which is characterized by the expansion of "economic" at all levels of socio-cultural reality. Everything around a person can be bought and sold, so it is impossible to stay away from exchange processes. Monetary relations penetrate into all spheres of society. And the value of things, cultural heritage and even human relations are determined by money as a universal value. Money has turned from a means of meeting needs into a major tool for the development of man and society as a whole.

Despite the extreme importance of money and monetary values in modern society, the problem of monetary identification remains almost unexplored, and therefore is relevant for research in the framework of the sociophilosophical discourse.

Some aspects of human identity in the context of monetary relations are revealed by Z. Bauman (2013), E. Fromm (1976), H. Marcuse (1964), G. Simmel (2004), V.V. Ilin (2007), and also V.G. Fedotova, V.A. Kolpakov, N.N. Fedotova (2008), who examine in detail the problem of identity in the context of the transformation of capitalism.

The study of the problem of monetary identification will help to understand the peculiarities of interaction of social actors in the modern world, and the definition of driving forces in the formation of monetary identity can become a prerequisite for overcoming crises in Western societies, including Ukraine.

\section{Research Methods}

As a follower of the concept of social transformations, initiated within the sociological theory by J. Alexander, I. Wallerstein, A. Giddens, S. Seidman and other researchers, we consider it appropriate to analyze the process of social identification of the individual in the context of certain socio-economic formations. This allows us to identify patterns in the development of social processes and phenomena, to consider social identification as a universal process in terms of ownership and disposal of basic material resources, to identify certain historical preconditions that contributed to the emergence and spread of a particular social identity in a given area. Also, a personal approach related to the attitude of the subject of identity to the objective social forms of consciousness is used. This is due to the need to explain the current social situation, which is still accompanied by the transformation of post-Soviet man in such areas as the revision of historical memory, the idealization of Western society as a model of civilization, the promotion of Western liberal and universal values. The latter gives grounds to look at the behavioral changes of social actors in terms of monetary relations as 1) systemically important for the vast majority of modern societies; 2) having unconditional value and changing the social behavior of a person under the influence of various lures of Western consumer society.
The purpose of the article is to study the monetary form of identity, which in our opinion arises due to the spread of values of Western culture in the world. The objectives of the article are to study the features of monetary identity, the prerequisites for its formation, and analysis of the impact of such identity on individual and society.

\section{Results and Discussion}

It is necessary to outline the concept of identity in general to define the concept of monetary identity. Problems of self-identification and identification received extraordinary attention of scientists in the late twentieth century. Any cultural, political, economic, national problem was considered through the prism of human identity.

In fact, the very concept of "identification" gets its socio-philosophical understanding in the 1940s thanks to E. Erikson (Erikson, 1968), who introduced the popular expressions "identity" and "identity crisis" into scientific circulation.

The term "identification" has an interdisciplinary nature, it is used in various scientific fields and in each of them it receives a special definition. In a more general sense, identification (Latin "identificare" - to identify) - is the assimilation, recognition, coincidence of objects. Identification is one of the most important mechanisms of socialization of the individual, which is manifested in the identification of the individual with a certain group or community (nominal or real, large or small, etc.) (Gritsanov, 2003: 400).

Human existence was quite clear and transparent within the framework of traditional society, and human identity did not raise questions. The social role that man played in society was the true essence of man. Identity was completely determined by a person's status, place in the social hierarchy, belonging to a certain community. Researcher V.A. Yadov notes that the desire of the individual to identify with a community arises after the destruction of the traditional way of life, where the need for self-determination is not relevant within the system of social relationships. In the case of the existence of an individual in a traditional society, group (social) status is determined by strict criteria of belonging to a community, class or stratum, as well as gender (Yadov, 1994: 36).

However, the traditional type of identity loses its meaning with the increasing pace of human life, when the globalization of life, the transformation of the world and human relations, pluralism in all spheres of life lead to increased human search for one's "self". The human personality is fragile and defenseless when faced with waves of globalization under the influence of which everything is neglected. The social status and social role of man are constantly changing, and therefore are not reliable enough to determine the essence of a person. A person tries to find the "self" by oneself.

In "late modern" society, according to A. Giddens, the complexities of social self-determination are exacerbated by the disruption of spatial and temporal coordinates and places of action of the individual (Giddens, 1991). Therefore, while in a traditional and even industrial society, the place of action, time perspective and space of social relations seem to be tied in a tight knot, in modern life, due to the active interaction of different cultures, including media, a person identifies oneself not only with the "here" and "now" communities, but also with "there" communities: both in the past and in the foreseeable future. The individual is thus included in the global system of social 
space, it becomes possible to rethink the experience of other cultures, there is an alternative for choosing one's own behavior. The formation of personality is implemented as a "reflective project" for which the person is responsible.

Thus, the modern man goes beyond traditional society, in which people had a clearly defined place and role, and their identity did not raise questions and was determined in advance. In a post-industrial society, the individual gains independence, loses his or her old place in the system of social relations, but does not gain new certainty. The disintegration of traditional society makes a person doomed to uncertainty, deprives him or her of an identity that corresponds to the social status, a place in the system of power relations. There has been a transition from proposed and natural identities to socially achievable, quasi-natural, and then to the chosen and socially acceptable ones (Fedotova, Kolpakov, 2008: 385-387).

Constant industrialization fundamentally changes the objective conditions of human life, forms the need for selfdetermination in relation to various groups and communities, and the dynamism and multilayered social relationships in one way or another necessitate the ordering of both dominant and peripheral "solidarities" (Yadov, 1994:36). Identity acquires a complex fragmentary character, and therefore it is not surprising that a person experiences a certain "crisis", collecting identity as a puzzle, which always lacks some pieces.

The so-called modern "identity crisis" is essentially the destruction of diachronic identity and the formation of synchronous one. Diachronic identity means the presence of an individual's unchanging identification core throughout life. In the context of diachronic identity, "being oneself" means not only going to the suprapersonal, collective, but also always being with one's past, one's values, actions, ideas in any life situation. This is exactly the identity possessed by man in traditional society.

The crisis of diachronic identity has the following features (Smovzhenko, 2015: 27-29):

- a person develops an instrumental and purposeful rational attitude to reality;

- the material monetary benefit is the main value of man;

- a person feels alienated from the universal values of national culture and has a skeptical and ironic attitude towards the world and others;

- the scale of the interests of modern man is narrowing to the limits of private life.

According to E. Fromm, a person begins to replace the question "what am I?" by the question "what do I have?" (Fromm, 1976). The researcher calls the type of person with a focus on "what do I have" the market type. Such an individual is focused on getting the maximum benefit from any life situation. A person runs away from oneself into new acquaintances, situations, new things, whole life becomes constantly changing. And even everything a person buys today will become boring tomorrow, they will always be able to replace everything with a new one. There is a constant change of human identity in the framework of continuous consumption.

Such a constant desire for change is a characteristic feature of modernity, and the constant search for the "self" indicates the variability of personal identity. Identity in this case does not have a permanent unchanged core, and therefore becomes not diachronic but synchronous (Smovzhenko, 2015: 27-29).

The destruction of diachronic identity and the formation of synchronous identity is quite logical against the background of transformational changes in all spheres of social life. Philosophical studies are of the opinion that modern society is formed as a result of the spread and rethinking of Western capitalist ideas. It is due to the growing value of money in capitalist society that people's social ties have gone beyond family clans, a new type of social differentiation has emerged not on the basis of blood kinship, but on the basis of property division and the territorial principle of tax collection. In the formation of the ideas of capitalism, man acquired his or her "self" to some extent due to the fact that money destroyed the traditional "us", and a person had to realize his or her individuality, opposition to the world, and seek support in oneself. So comes the discovery of personality. And in the capitalist world, man finds his or her belonging to an infinitely wide variety of things, people and events that have opened up to through commodity-money relations, and discovers that one really belongs to this boundless, but unique world - that is how the transition to universality happened (Smovzhenko, 2015). Way of thinking and scale of values changed.

In this case, the identity crisis appears as a completely logical and justified phenomenon, because it is an indicator of human adaptation to changes in the world around. The problems that a person faces experiencing a "crisis" should not trap him or her, but appear only as a challenge, as an opportunity to change themselves and the world around them. A person experiencing an identity crisis tries to find his or her "self" Modern man is a man who is free to choose the image of his or her "self", and the search for standards of their own identity is carried out due to both subjective and objective circumstances. Man is able to choose his or her "self" independently and only to reconcile it with the values of social space. Of course, in the social space there are ready-made models for the formation of one's own identity, which a person can choose.

Each epoch sets its own role models and produces its own values. In the process of socialization, man absorbed, rethought, and reproduced them. However, it was under the flourishing of capitalism and its transformations, as well as the globalization processes that served to spread pluralist tendencies around the world, that man was able to choose from an unlimited number of models for his or her own identity.

Not surprisingly, one of the values that a person focuses on in the process of identification is money. Money reflects the position of man within the traditional division along the rich-poor axis. However, in different eras, the social value of money was not always recognized. Thus, S. Gluzman believes that the history of the relationship between man and money is similar to the pendulum swinging between two poles, namely the desire and contempt. For millennia, from the time of the first civilizations of Mesopotamia to the fall of the Roman Empire, the pendulum of human relations was on the pole of worship of money. It was first swung in the other direction by the early Christians. The church wanted to see money only as a means of payment and exchange. And only in the Renaissance and Protestantism this pendulum swung again and stopped at the pole of desire. According to the 
researcher, it is in the era of capitalism that the attitude to money begins to be guided by the principle "the more money, the better" (Gluzman, 2007: 68). Within the framework of capitalist society, an unusual idea of the value of money begins to form both for individuals and for society as a whole.

In the framework of socio-philosophical research, capitalism should be considered as "a characteristic of the behavior of a particular social structure as a whole, and not just a special way of doing business" (Fedotova, Kolpakov, 2008: 386).

However, the term capitalism is less and less used to denote the current stage of development of society. According to I.P. Buleev, N.E. Bryukhovetskaya, capitalism as a socio-economic formation or stage of socioeconomic development has compromised itself with periodically recurring local, regional and global financial and economic crises, wars, revolutions, uprisings, strikes, exploitation of the population of one's own and other countries, colonies, irrational use of natural resources, destruction of human habitats, flora and fauna, etc. (Buleev, Bryukhovetskaya, 2018).

Therefore, in the modern world, the term "capitalism" is being replaced by others. Capitalist society is called "social-democratic", "people's-democratic", society of "general welfare", "post-economic", "neo-industrial", "information", society of "western type" and so on. However, the value of money for the modern world remains undeniable, and therefore is remains extremely important to trace its impact on human awareness of their own "selves".

Therefore, deriving the term "monetary identity", we try to define the essential elements of modern man, to determine his or her attitude towards money, both conscious and unconscious one, explain why a person begins to be guided by monetary values not only in business, economic life, but also in personal, everyday behavior. It is through the notion of monetary identity that we try to explain the penetration of such an undeniably important sphere of life as economic into other spheres.

Monetary identity arises in the context of the historical development of goods-money relations, in accordance with the formation of certain patterns of behavior towards the possession of money. There is a division into rich and poor. Money not only plays the role of a medium of exchange, but also acquires social significance. One or another attitude to money, possession of it, wealth or poverty - all these are aspects that have influenced a person's awareness of their place in society and the role of others. A special, modern vision of monetary identity is formed within the framework of capitalist society, under the conditions of the possibility of free choice of one's own identity.

Modern monetary identity in a broad sense is a public identity that arises from the spread of the Western type of management with its corresponding values. In a narrow sense, monetary identity is the identity of individual groups and people that exist within the modern capitalist system. The emergence of monetary identity, as we understand it, was preceded by the following structural and cultural changes in society in the process of modernization: the destruction of the class system of inequality; industrial revolution, urbanization, which destroys traditional (family, community, neighborhood) social ties, differentiation of culture, and others. Monetary identity arises in a "Western society" in which there is a "market economy, legally protected private property, civil society, democracy, the rule of law, class stratification, mass production, mass culture". A common human ideal is the image of a rich man, businessman or businesswoman that is able to earn money without extraordinary efforts and spend money improving their own lives.

However, it should be understood that monetary identity has changed in accordance with the transformations that capitalism has undergone. Thus, according to Fedotova V.G., Kolpakov V.A., Fedotova N.N., there has been a consistent change of three types of modernity, in which a person has a different identity, on a capitalist basis ( $\mathrm{Fe}-$ dotova, Kolpakov, 2008: 386-387).

The first type of modernity (liberal modernity) arises due to the weakening of traditional relations in society and is characterized by the emergence of "modular man", an economic man whose autonomy and independence in society was institutionally and culturally supported.

The second type of modernity (organized modernity) allowed to determine social identity by belonging to a social class. Class affiliation was fixed and could be changed. The class identity of this period is quasi-natural. The individual was born and socialized under this scheme, the probability of moving from one class to another was low. Therefore, this identity had created a strong social basis for constructing a collective identity. The Second Modernity dealt with the mass man who became a consumer in a consumer society.

The third type of modernity, formed since the 1990s, is characterized by the blurring of the boundaries of class structures. The probability of change of class increases. It was important for the formation of identity to reduce the influence of economically determined class position. Individuals were given the opportunity to independently construct or change communities to make them matching their desired social identity. Man is trying to master the features of the First Modernity, be economical, and be the mass consumer in line with the Second Modernity. Researchers note that the dynamics of these properties is very disturbing: "alienation, loneliness, selfishness and narcissism grow, the mass man is formed by the media, without the classical features of mass (mediocrity)" (Fedotova, Kolpakov, 2008: 387).

V. Ilin uses the term "financial civilization" to explain the peculiarities of Western society. Highlighting monetary values as one of the main values for modern society, the researcher notes that there is the penetration of the monetary dimension at all levels of socio-cultural life, including in areas that have not yet been measured by monetary equivalent (Ilin, 2007). In addition, in modern society there is a situation in which money acts solely for the sake of money itself, virtualizing not only the economy but also society as a whole.

In the context of financial civilization, modern money is a substance-subject, completely ideal, spiritual, abstract one, which does not need any other substance than itself. This substance is born of economic relations and is in economic parameters, but permeates the whole world, putting into effect the real world money, or world currencies. Money occupies a dominant position in financial civilization, "conquering everything" (Ilin, 2007: 396).

It is impossible to imagine a modern society without money. One way or another, something will be a universal medium of exchange, and therefore it will be money. 
Modernity cannot exist without money, because the rejection of them implies a return to natural exchange, which we cannot allow, because it would serve as a rapid decline in living standards. Therefore, now we are dealing with a person who lives in a financial civilization, exists by its rules and shares its values. A person is forced to accept the "rules of the game" defined by the majority, because refusing them will be ground to exclude this person from the system of social relations.

In identification, man is accustomed to relying on those values and guidelines that are recognized by society. Therefore, such a generally approved value as money is easily accepted by man. The formation of monetary identity is preceded by the fact that the possibility of a person to choose from a variety of objects of purchase begins to be implemented through money, and therefore a person with money allegedly has the freedom, freedom to choose and freedom to buy or not buy. Of course, this freedom is not always exercised in modern society, consumer, mass culture is successfully "sold" to people at all levels of the media, and it becomes almost impossible to disregard it.

Simmel notes that with the growth of exchange processes in the modern world, money is beginning to act as a universal medium of exchange. And while previously the value of money for a person was expressed only in the form of things could be bought with them, now their value lies in the universality of money as a means of exchange. Money becomes a universal value, greater than the value of individual things that can be obtained with it (Simmel, 2004: 232).

Modern man craves "easy money" for which it is not needed to work hard and wants money in general as a universal value. Money provides an opportunity not only to improve the objective circumstances of life, to raise the standard of living, but also to satisfy the subjective inner desires to be no worse than others, to possess not only material well-being but also public recognition. In order to achieve public recognition, a person turns to symbolic, status consumption.

In the context of globalization processes, monetary identity is transformed into a universal identity, a global identity. It covers all societies. We do not mean that the worldview and cultural frameworks between the civilizations of East and West are disappearing, but only that money is becoming a universal value for every society. And while other values of Western culture remain less common, money is a necessary element of exchange in almost any society. The value of money was recognized before the spread of capitalism, and therefore in the modern era, money only increases its influence on human consciousness and becomes a more important part of the identity of each individual.

All of the above leads us to believe that modern man is stuck in an attempt to combine economic origin, which is extremely strong in the modern era, and social origin, and this is accompanied by internal psycho-emotional tension. At the heart of the economic man are the values of rationalism, and the focus on obtaining the maximum benefit from putting the least amount of effort. A person feels the "tilt" of their own values in the direction of the material values. Spiritual values are suppressed by attempts to meet all needs within a consumer society. The boundaries between economic and social man are blurring.

ISSN 1728-9343 (Print)

ISSN 2411-3093 (Online)
An economic man, or a "market man", determines his or her identity through the things he or she has. A social person is a person abstracted from the personal goals in society, he or she is guided by the emotions, values and traditions of society, it is important for him or her how they are perceived by others. Thus, the economic component ensures survival and personal development, and social component involves the development of personality only in the context of joint life activity. The idea of survival and development, the desire to improve their own lives are inherent in man genetically. At the same time, one of the main needs of a person is to obtain social approval of his or her actions, behavior, worldview, etc. Money, which serves to construct identity, is able to meet the needs of both economic and social components of man. In man, the social and the economic merge, forming a monetary identity.

The image of modern man, in this case, may seem quite limited. Indeed, H. Marcuse draws attention to the limited perception of the world around man. The researcher calls modern man "one-dimensional", i.e. one that exists in the "one-dimensional" society. He notes that instrumental rationality has become the main reason for the growth of crisis phenomena in the human life world to such an extent that it has become its own opposite. In his work "One-Dimensional Man" (Marcuse, 1964) he highlights the following features of modernity:

- people in modern society are essentially the same, because they are guided by the same desires;

- neo-totalitarianism hides behind the modern free and liberal society - a society of mass consumption exerts influence on culture and spreads its own values to control each individual;

- the needs of modern man are erroneous and imposed on him or her from the outside.

"One-dimensionality" is not reduced to the power of money over man. It must be considered much more broadly - it is the total control of society over the individual existence of man, which differs from previous forms of totalitarianism by the penetration of social control in areas previously unattainable for the unifying influences of society. According to the researcher, money appears here only as a very convenient and effective tool for totalization. Following the ideas of $\mathrm{H}$. Marcuse, we can assume that modern monetary identity is to some extent imposed on us, it becomes an artificial mechanism for controlling human behavior.

Positive changes in society will be possible only when people carry out a "Great Refusal" - change the direction of their needs from the exploitation of nature to harmony with it, turning their desires and feelings to high spirituality.

Despite the above, it becomes almost impossible to set aside the benefits of modernity that we have received with modernization. "Sneer if you like at our cushy modern affluence - our comfortable homes, abundant food, recreation and entertainment, health and longevity - but please compare it against the lives of our forebears", which according to Frank S. Robinson, was far from so comfortable (Robinson, 2011: 29). Over the past century, average real incomes around the world have increased 5 times. The average person lives five times better today than they did in 1900. Such economic growth can easily be explained by senseless greed and for the poor around the world, economic growth is the way out of poverty. In 
the last two decades, a billion people have risen from extreme poverty to a decent standard of living. This is the most important human value of capitalism.

On the other hand, we should not forget that the stimulus of capitalist production is the race for profit. But to make a profit, it is needed to sell the created product. And this requires paying buyers and the constant existence of demand. The growth of people's living standards has ensured guaranteed sales of ever-increasing output. Thus, according to Semenov Yu. I. there is a society of mass consumption, or consumerism (Semenov, 2003).

In a study of consumer culture, Eric J. Arnould and Craig J. Thompson drew attention to the relationship between consumer identification projects and the structuring impact of the market. According to them, in the modern market space, certain types of consumer positions can be seen, which consumers can choose for themselves. Such consumer positions predetermine both a person's goals and desires and certain cultural scenarios in which the personal identity of each individual is consistent with the structural imperatives of a global consumer-oriented economy (Arnould, Thompson, 2005).

Douglas B. Holt describes in detail how the postmodern economy thrives by producing "unruly bricoleurs" that express personal sovereignty and claim personal authenticity through nonconformist acts of consumption and thus place the market and its symbols at the center of their identity (Douglas B. Holt, 2002). Within the capitalist system of cultural production, the desire of consumers to strive for certain identities and ideals of lifestyle is stimulated.

As Yu. I. Semenov notes, there is a formation of more and more artificial needs for things that people really do not need at all. The most important tool is intensive obtrusive advertising (Semenov, 2003). People are strongly persuaded that only the presence of certain things will provide them with prestige. Public opinion arises and is affirmed, condemning those who do not have these things, and their owners are glorified. A new form of prestigious economy emerges and is approved.

Thus, modern mass culture and the media play a huge role in shaping identities. They produce and replicate cultural models and types that serve as a role model for many people to create "self-images". Such prototypes for the construction of identity are TV presenters and movie stars, heroes of TV series and movies, out sports celebrities and others. The media broadcasts not only ready-made examples to follow, but also ideas of a carefree life, beauty (created by surgeons, which is not mentioned) and "easy money" that can be won or even borrowed to get everything you want. A person learns from the media what they should be like in order to be liked by everyone, the image of an "ideal", successful and beautiful person who consumes only the "best" goods is formed.

The culture of consumption appeals to the social nature of a person, promises to give him or her unity with others and at the same time allegedly gives the opportunity to be unique, to find one's "self", to stand out from others, to have a unique identity. Due to consumption, a person thinks that he or she can satisfy all desires, even conflicting ones.

At the same time, another facet of the influence of monetary values is revealed. The monetary identity imposed on a person is felt as empty and meaningless one, it does have a higher meaning and does not serve the spiritual needs of man. Therefore, it turns out to be somewhat "unhealthy".

Exploring the prospects for the development of man and society, V. Ilin draws attention to the weakening of the value-spiritual barrier, which led to the loss of the "centerline" of man and society (Ilin, 2011: 20). As a result of total individualization, collectivism and community are finally destroyed, and as a result, there is a radical change in the moral foundations of life.

In this world, fundamental moral values are questioned, evidence-based mastery of the world is discredited, rational patterns of behavior threaten the loss of "all that is holy", and human life is reduced to an endless pursuit of money. Money has evolved from an instrument of economic activity to one of the dimensions of human destiny, as wealth and poverty are not only external circumstances of life, but also a range of existential patterns in which one experiences one's existence in the world, a "sense of triumph" or humiliation and frustration (Smovzhenko, 2015).

In the conditions of financial civilization, friendship loses its meaning, people become partners who work together for profit. Money becomes the most reliable friend of a person, which relieves humiliation, creates conditions for freedom and opportunities for selfrealization. The individualism (egoism) of man turned him or her into an "atom" of social life, there is an alienation from society, from the system of cultural values. This has led to the differentiation of social life and exacerbation of contradictions between its various groups and strata (Ilin, 2011: 22).

A special aspect of identity formation is that money is part of everyday life. Depending on what amount of money an individual has, his or her capabilities and desires are determined, ideas are formed about exactly how to dress, what to eat, where to spend time. Money provides many opportunities, possession of them opens the whole world to man. A person who has monetary wealth can implement almost any desire. Money is the object of envy, a value that people "hold on" to, because it helps to determine a person's place in society, his or her influence, thanks to them the path to power and knowledge that is not available to others is paved.

A person's success rate coincides with his or her position within the system of assessing wealth and poverty. The person's self-concept depends on how much money he or she has, on what products he or she can afford. And accordingly, human happiness begins to be measured in monetary terms. Money becomes a measure not only of the material but also of the spiritual world. All these are signs of an unhealthy monetary identity.

In the context of the above, ideas may indeed arise to carry out the "Great Refusal", but not many people would dare to act so categorically. A critical thinking of a person's own needs, ideals and goals would serve to form a healthier monetary identity with appropriate behavior and worldview. Critical thinking would help to form more realistic examples of identity, cut off all that is superfluous, and understand that while money is the easiest way to gain recognition, there are other cultural forms of selfexpression that can really serve to build a more secure identity. We should not forget that in today's world, success is more likely to be achieved not by those who chase money, but by those who follow their dream in an organized manner. 


\section{Conclusions}

In the modern world, people are experiencing an "identity crisis", they have lost their identities that they had in a traditional society from birth. The unchanging, permanent identity is now imagined only as an incomprehensible dream. Clear and reliable diachronic identity, which served as a support in all situations of life, is lost. Synchronous identity does not meet the needs because it must be reconstructed every time, choosing from the options offered by social reality.

Man has achieved the desired freedom of choice, and can now choose one's own personality at one's own discretion. The direction of the search for identity is determined by the person, guided by his or her own will. Of course, the outside world can always be disregarded and person can form the image of "self" independently, but for its recognition it is necessary to turn to society and social values. Characteristic of the modern era is that the search for identity is mixed from the direction of the vector "who am I?" to the vector "what do I own?". The search for a new identity, namely monetary identity, is influenced by the following aspects that arise in connection with the expansion of Western civilization: formed purposeful rational, instrumental attitude to reality in which the world serves to meet human needs; a person begins to feel alienated from the general values of national culture, and his or her behavior is determined by individual, even selfish motives; the main value for man is money, which is also a universal value, the equivalent of all other material values.

With the acceleration of the pace of life, modernization and globalization processes that serve to spread the values of Western culture, new values and new ways of life are imposed on a person, forming the basis of his or her identity. Rationality penetrates into human life and conquers all its activities. The search for identity also becomes a rational process. A person seeks to receive from life as many benefits as possible, while spending little effort.

Within a capitalist society, man perceives money as a tool that makes the process of obtaining goods as simple as possible. Money is becoming a universal means of exchange and communication. And the more money you own, the more goods and products you can buy and the more often you can replace them with each other in case you get bored. Buying certain goods, in particular under the influence of the media, which through advertising form a positive image of people who own a product, a person is convinced that it becomes if not "better" than others, then, at least, not "worse" than they are. In connection with the above, monetary identity appears to be imposed by a capitalist, profit-oriented society, and a person with a monetary identity buys everything to achieve at least a little of the "ideal" of a person formed in the media. Such an identity is somewhat unhealthy and requires a critical rethinking of one's own values and needs and bringing to the fore precisely those values that can actually be achieved and the achievement of which will make a person's life truly better.

However, we emphasize that man is not a characterless being and by critically rethinking his or her own life, the person can always choose other role models that will not contradict social trends and give space for personal development. The quality of life of modern man also depends on themselves, and the renunciation of money and consumption is not necessary to overcome the modern identity crisis. Monetary identity is an important component of human life in society, but it should not define the human essence completely. A healthy identity, and in particular a healthy monetary identity, can be formed only as a result of a person's work on oneself and the definition of the own key values and examples in life, and a critical rethinking of the patterns provided by society. Formation and dissemination of positive human standards of harmoniously developed, purposeful, hardworking, etc. person in the world can help a person in finding one's own "self".

\section{REFERENCES}

Arnould, Eric J. \& Thompson, Craig J. (2005). Consumer Culture Theory (CCT): Twenty Years of Research. Journal of Consumer Research, 31 (4): 868-882, https://doi.org/10.1086/426626

Bauman, Z. (2013). Liquid modernity. John Wiley \& Sons https://drive.google.com/file/d/1VEdYdJ-gstJMPL23OYwGzqDci3XDqSW/view?usp=sharing

Buleev, I. P., Bryukhovetskaya, N.Ye. (2018). Komparativnyy analiz dvizhushchikh sil kapitalisticheskoy i sotsialisticheskoy ekonomik: vozmozhnosti primeneniya $v$ Ukraine. https://www.problecon.com/export pdf/problems-ofeconomy-2018-2 0-pages-276 288.pdf (In Russian).

Holt, Douglas B. (2002) Why Do Brands Cause Trouble? A Dialectical Theory of Consumer Culture and Branding. Journal of Consumer Research, 29 (1): 70-90. DOI: https://doi.org/10.1086/339922

Erikson, E. H. (1968). Identity: Youth and crisis (No. 7). WW Norton \& company.

Fedotova, V.G. \& Kolpakov, V.A. \& Fedotova, N.N. (2008). Globalnyy kapitalizm: tri velikie transformatsii. Moscow: Kulturnaya revolyutsiya. (In Russian)

Fromm, E. (1976). To Have or To Be? London: Continuum. URL: https://giuseppecapograssi.files.wordpress.com/2013/08/eric h-fromm-to-have-or-to-be-1976.pdf

Giddens, A. (1991). Modernity and self-identity: Self and society in the late modern age. Stanford university press.

Gritsanov, A. A. (2003). Noveyshiy filosofskiy slovar (Ed.3). Minsk: Knizhnyy Dom (In Russian) (In Ukrainian)

llin,V.V. (2007). Finansova tsivilizatsiya. Kyiv: Knyga, 528 pp.

llin,V.V. (2011). Finansova tsivilizatsiya v perspektivakh rozvytku lyudyny i suspilstva. Filosofiya finansovoï tsivilizatsiï: Iyudina u sviti groshey: Conference Papers, Lviv: 16-25. URL: http://kk.nau.edu.ua/article/1369 (In Ukrainian)

Marcuse, H. (1964). One-Dimensional Man: Studies in the Ideology of Advanced Industrial Society, https://libcom.org/files/Marcuse, $\% 20 \mathrm{H} \% 20-\% 200$ ne-

Dimension-

al\%20Man, \%202nd\%20edn.\%20(Routledge,\%202002).pdf

Robinson, Frank S. (2011). Capitalism \& Human Values. Philosophy Now. 83: 28-31. https://philosophynow.org/issues/83/Capitalism and Human Values

Semenov, Yu. I. (2003). Filosofiya istorii. (Obshchaya teoriya, osnovnye problemy, idei i kontseptsii ot drevnosti do nashikh dney). Moscow: Sovremennye tetradi. (In Russian).

Simmel, G. (2004). The Philosophy of Money. London-New-York: Rutledge. http://www.eddiejackson.net/web documents/Philosophy\%20of\%20Money.pdf .

Sitkevich, N. V. (2011). Problema identifikatsii cheloveka v informatsionnom obshchestve skvoz prizmu mirovozzrencheskikh izmeneniy. Gramota, 3 (9), Ch. III: 149-151 (In Russian)

Smovzhenko, T. S. et all (2015). Ukrainska lyudina $v$ evropeyskomu sviti: vimiri identichnosti. Kyiv: UBS NBU. (In Ukrainian)

Yadov, V. A. (1994). Sotsialnaya identifikatsiya $v$ krizisnom obshchestve. Sotsiologicheskiy zhurnal. 0(1): 35-52. https://www.jour.fnisc.ru/index.php/socjour/article/view/35/36 (In Russian). 
Тетяна Безпрозванна,

Київький університет імені Бориса Грінченка (м. Київ, Украӥна)

e-mail: t.bezprozvanna.asp@kubg.edu.ua,ORCID 0000-0003-2056-4922

\section{ГРОШОВА ІДЕНТИФІКАЦІЯ ЛЮДИНИ ЯК ПРОДУКТ ПОШИРЕННЯ ЦІННОСТЕЙ ЗАХІДНОї ЦИвІЛІзАЦії}

Стаття присвячена проблемі грошової ідентичності, яка в контексті трансформаційних процесів сучасного світу потребує детального вивчення. Актуальність дослідження полягає в тому, що ідентичність сучасної людини стає хиткою. В пошуках орієнтирів для конструювання власного «я» людина опиняється на роздоріжжі. Вона втрачає ідентичність, якою володіла від народження, як член традиційного суспільства, і вимушена вибудовувати її самостійно. В рамках статі розкриваються передумови виникнення кризи ідентичності в контексті розвитку капіталізму та формуванні економічного типу людини. Мета статі полягає у визначенні особливостей формування грошової ідентичності, що стала по суті побічним продуктом поширення цінностей Заходу. Для досягнення цієї мети здійснюється структурно-функціональний аналіз соціальних взаємодій суб'єктів ідентифікації, а також використовуються загальнонаукові методи синтезу і узагальнення матеріалів, аналізу, порівняння, дедуктивний, індуктивний методи та ін. Основні риси грошової ідентичності полягають в тому, що людина починає керуватися власними егоїстичними началами, а гроші стають головною цінністю для людини, постають як універсальна цінність, що є еквівалентом усіх інших матеріальних цінностей. Грошова ідентичність в рамках сучасного світу постає як глобальна та нестійка, вона формується штучно і слугує сучасному ринку для отримання прибутку в рамках суспільства споживання. Зроблено висновок, що у сучасному світі гроші слугують не лише покращенню об'єктивних обставин життя, а і стають засобом досягнення суспільного визнання. Проблема грошової ідентичності виявляється особливо актуальною і для України, як для країни, що орієнтується на західний тип господарювання 3 його досягненнями, цінностями і водночас проблемами, а тому потребує подальших досліджень.

Ключові слова: грошова ідентифрікація, ідентичність, криза ідентичності, капіталізм, гроші, грошові цінності, західна цивілізація.

(C) Tatiana Bezprozvanna

Надійшла до редакції: 15.09.2021

Прийнята до друку: 04.10.2021 